\title{
Selection for wide adaptability and high phenotypic stability of Brazilian soybean genotypes
}

\author{
V.M. Oliveira ${ }^{1}$, O.T. Hamawaki ${ }^{2}$, A.O. Nogueira ${ }^{3}$, L.B. Sousa ${ }^{2}$, F.M. Santos ${ }^{4}$ and \\ R.L. Hamawaki ${ }^{5}$ \\ ${ }^{1}$ Universidade Estadual de Goiás, Palmeiras de Goiás, GO, Brasil \\ 2Instituto de Ciências Agrárias, Universidade Federal de Uberlândia, \\ Uberlândia, MG, Brasil \\ ${ }^{3}$ Instituto de Genética e Bioquímica, Universidade Federal de Uberlândia, \\ Uberlândia, MG, Brasil \\ ${ }^{4}$ Goemil, Palmeiras de Goiás, GO, Brasil \\ ${ }^{5}$ Universidade Federal de Uberlândia, Uberlândia, MG, Brasil \\ Corresponding author: V.M. Oliveira \\ E-mail: valeciamo@yahoo.com.br \\ Genet. Mol. Res. 15 (1): gmr.15017843 \\ Received October 19, 2015 \\ Accepted December 3, 2015 \\ Published March 31, 2016 \\ DOI http://dx.doi.org/10.4238/gmr.15017843
}

ABSTRACT. Advances in genetic enhancement techniques have led to an increase in soybean production. Thus, soybean is currently one the most economically important cultured species worldwide. The objectives of the present study were to study the interaction of soybean genotypes per environment in terms of grain productivity and to evaluate their phenotypic adaptability and stability, with the final aim of selecting lineages with high productivity, wide adaptability, and high stability. Seven soybean genotypes, consisting of five lineages developed by the soybean genetic enhancement program of the Universidade Federal de Uberlândia (Brazil) and two controls, were evaluated during several annual cycles in seven different environments. A randomized complete block design (RCBD) with three replicates was adopted in each site. This study followed the methodology 
proposed by Eberhart and Russel and Lin and Binns, with modifications by Carneiro, and the AMMI (additive main effects and multiplicative interaction model) analysis. The average productivity of soybean cultivars in the trials was $2739.26 \mathrm{~kg} / \mathrm{ha}$. The L01V13 genotype and the UFUS Guarani cultivar had wide adaptation according to the methodology proposed by Eberhart and Russel and Lin and Binns, with modifications by Carneiro. When analyzed with the AMMI model, the UFUS Guarani cultivar showed high stability. In general, the methodologies studied are complementary and, when used together, increase the reliability of the classification, providing support for the use of specific soybean cultivars in different environments.

Key words: Glycine max; G x E interaction; Grain productivity

\section{INTRODUCTION}

Soybean [Glycine max (L.) Merrill] is one of the most important exported crops in the world. The expansion of agricultural frontiers, together with an improvement of environmental conditions and genetic enhancement, have led to an increase in soybean production (Oliveira et al., 2012; Chawla et al., 2013). The worldwide production of soybean crops in 2013/14 was 283.54 million tons, with an average productivity of $2541 \mathrm{~kg} / \mathrm{ha}$. The United States was the largest soybean producer, with 88.66 million tons produced in 2013 (Rural Economy Department, 2013). Brazil was the second largest producer, with 86.12 million tons produced and a productivity of $2854 \mathrm{~kg} / \mathrm{ha}$ (CONAB, 2014).

This leguminous plant grows well in different environments, taking advantage of the local conditions in different regions (Oliveira et al., 2012). To increase the possibility of selecting superior genotypes and to study the interaction of genotypes per environment ( $\mathrm{G} \times \mathrm{E}$ ), developed lineages are usually included in trials of value for cultivation and use (VCU) (Malosetti et al., 2013). The $\mathrm{G} \times \mathrm{E}$ interaction in trials refers to the different patterns of responses among genotypes across different environments. This interaction can be simple, when it shows the difference in variability among genotypes across environments, or complex, when it denotes differences in the same genotype across different environments, indicating inconsistent behavior of genotypes when grown in different environments (Cruz et al., 2012).

One of the objectives in a genetic enhancement program is the development of genotypes with high productivity, together with wide adaptability and production stability (Lemos et al., 2011). Different statistical methods allow the identification of stable genotypes that can growth in different environments (Sediyama et al., 2005). Among the methodologies available to evaluate the adaptability and stability of genotypes are the parametric methods based on linear regression described by Eberhart and Russel (1966). These methods identify genotypes with wide adaptation or stable genotypes with specific adaptation to favorable environments (medium and high productivity) and unfavorable environments (low productivity) (Silva and Duarte, 2006). Nonparametric methods to identify superior genotypes in favorable and unfavorable environments, such as the one developed by Lin and Binns (1988) and modified by Carneiro (1998), are also available. This method does not limit the use of regression and enables the identification of one or more cultivars with performance close to their maximum in the tested environments (Silva and Duarte, 2006). In addition to the above methodologies, there are multivariate analyses that check 
the crop adaptability and stability. Among the multivariate methods, the additive main effects and multiplicative interaction (AMMI) methods have been used successfully to evaluate the effects of the G x E interaction (Silva and Duarte, 2006; Ramalho et al., 2012).

In the present study, the $G \times E$ interaction was analyzed for soybean productivity. In addition, the phenotypic adaptability and stability of soybean lineages developed at the genetic enhancement program of the Universidade Federal de Uberlândia (Brazil) were evaluated. This study followed the methodology proposed by Eberhart and Russel (1966), Lin and Binns (1988), with modifications by Carneiro (1998), and the AMMI analysis (Amira et al., 2013).

\section{MATERIAL AND METHODS}

\section{Genetic material}

Seven soybean genotypes, consisting of five lineages developed by the soybean genetic enhancement program of the Universidade Federal de Uberlândia (Brazil) (L01V13, L02V13, L03V13, L04V13, L05V13) and two controls (UFUS Guarani and M-SOY6101), were evaluated during several annual cycles. The main characteristics of the controls are described in Table 1.

Table 1. Characteristics of the two controls used in the value for cultivation and use trials.

\begin{tabular}{l|c|l|c}
\hline Cultivar & Cycle & Region & Productive potential (kg/ha) \\
\hline 1UFUS Guarani & 120 & GO, MG, BA, MT, TO & 4500 \\
\hline${ }^{2}$ M-SOY6101 & 105 to 110 & MS, GO, SP, MT & 3600 \\
\hline
\end{tabular}

${ }^{1}$ Cultivar developed by the soy enhancement program of the Universidade Federal de Uberlândia (UFU). ${ }^{2}$ Cultivar developed by Monsanto (Uberlândia, MG).

\section{Cultivation sites}

Trials were performed in seven environments, covering four municipalities and three agricultural seasons, according to Table 2. Site choice was done according to the interest the different producing regions have shown in a new cultivar.

Table 2. Altitude, latitude, longitude, and crop season of the soybean genotype trials in Goiás and Bahia.

\begin{tabular}{l|c|c|c|c}
\hline Environment & Altitude $(\mathrm{m})$ & Latitude & Longitude & Season \\
\hline Urutaí - GO & 751 & $17^{\circ} 29^{\prime} 20.30^{\prime \prime}$ & $48^{\circ} 12^{\prime} 50.19^{\prime \prime}$ & $2010 / 11$ \\
\hline Goiatuba - GO & 761 & $18^{\circ} 00^{\prime} 17.22 "$ & $49^{\circ} 15^{\prime} 35.08^{\prime \prime}$ & $2011 / 12$ \\
\hline Urutaí - GO & 751 & $17^{\circ} 29^{\prime} 20.30^{\prime \prime}$ & $48^{\circ} 12^{\prime} 50.19^{\prime \prime}$ & $2011 / 12$ \\
\hline Palmeiras de Goiás - GO & 654 & $16^{\circ} 50^{\prime} 02.19^{\prime \prime}$ & $49^{\circ} 52^{\prime} 46.34^{\prime \prime}$ & $2011 / 12$ \\
\hline Luiz Eduardo Magalhães - BA & 760 & $12^{\circ} 05^{\prime} 38.93^{\prime \prime}$ & $45^{\circ} 46^{\prime} 06.60^{\prime \prime}$ & $2011 / 12$ \\
\hline Palmeiras de Goiás - GO & 654 & $16^{\circ} 50^{\prime} 02.19^{\prime \prime}$ & $49^{\circ} 52^{\prime} 46.34^{\prime \prime}$ & $2012 / 13$ \\
\hline Luís Eduardo Magalhães - BA & 760 & $12^{\circ} 05^{\prime} 38.93^{\prime \prime}$ & $45^{\circ} 46^{\prime} 06.60^{\prime \prime}$ & $2012 / 13$ \\
\hline
\end{tabular}

\section{Preparation and execution of trials}

Before planting the soils of the different trials, soil samples were collected and analyzed in order to plan the appropriate liming and fertilization schemes for each trial. Therefore, a correction for differences among soil types was not necessary. A tillage system was used, in which desiccation was performed with the active ingredients glyphosate and 2,4-D (3.5 and 0.5 L/ha, respectively) 
before manual sowing. After 7 days of desiccation, the area was grooved and fertilized according to the soil analysis of each site. A standard seeder was used according to Ribeiro et al. (1999).

Seeds were treated with the systemic fungicide Metalaxyl and the contact fungicide Fludioxonil (100 $\mathrm{mL}$ product per $100 \mathrm{~kg}$ seeds), and with the systemic insecticide Thiamethoxam (200 mL product per $100 \mathrm{~kg}$ seeds). Then, seeds were inoculated with Biomax (150 mL per $50 \mathrm{~kg}$ seeds; $7 \times 10^{8}$ cells $/ \mathrm{mL}$ Bradyrhizobium per seed). The strains SEMIA 5079 and SEMIA 5080 were present in the inoculant.

The control of weeds, pests (bugs and caterpillars), and diseases (Asian rust, anthracnose) were carried out whenever necessary, according to the technical recommendations appropriate for each crop (EMBRAPA, 2010, 2011).

\section{Experimental design}

A randomized complete block design (RCBD) with three replicates was adopted in each site. The parcels consisted of four rows ( $5 \mathrm{~m}$ long) of soybean plants, spaced $0.5 \mathrm{~m}$ from each other, with a total area of $10 \mathrm{~m}^{2}$. The useful parcel area consisted of the two central rows, excluding $0.5 \mathrm{~m}$ from each end, with a total area of $4 \mathrm{~m}^{2}$. Twenty seeds were manually distributed per meter, resulting in a population of 400,000 plants/ha.

\section{Determination of grain productivity}

To determine grain productivity $(\mathrm{kg} / \mathrm{ha})$, the useful area of each parcel was manually harvested 10 days after plants had reached the R8 stage (Fehr and Caviness, 1977). Plants were threshed and the grains were manually treated. The obtained data ( $\mathrm{g} /$ parcel) were transformed to $\mathrm{kg} / \mathrm{ha}$ and corrected for $13 \%$ humidity, according to the following equation:

$$
P F=P I \frac{(100-U I)}{100-U F}
$$

where $P F$ is the final weight of the sample (corrected weight), $P I$ is the initial weight of the sample, $U I$ is the initial humidity of the sample, and $U F$ is the final humidity of the sample $(13 \%)$.

\section{Statistical analysis}

Grain productivity in each environment was initially analyzed using analysis of variance (ANOVA). The existence of homogeneity of the residual variance was checked, whereby homogeneity was considered to occur when the ratio between the highest and lowest residual mean square was lower than seven. In that case, a joint analysis was performed as described by Ramalho et al. (2012). Genotype and environment were considered fixed effects. To estimate the complex parts of the $G \times E$ interaction, analyses of variances were performed among pairs of environments, according to Cruz and Castoldi (1991):

$$
\mathrm{C}=\sqrt{(1-\mathrm{r})^{3}} \sqrt{\mathrm{Q}_{1} \mathrm{Q}_{2}}
$$


where $Q_{1}$ and $Q_{2}$ are the mean squares of genotypes in environments 1 and 2 , respectively, and $r$ is the correlation between genotype means in environments 1 and 2.

Phenotypic and genotypic correlations between pairs of environments were described by:

$$
r f=\frac{\operatorname{COV}\left(Y_{i j^{\prime}} Y_{i j^{\prime}}\right)}{\sqrt{\hat{V}\left(Y_{j}\right) \hat{V}\left(Y_{j^{\prime}}\right)}}
$$

where $\operatorname{COV}\left(Y_{i j} Y_{i j}\right)$ is the phenotypic covariance of grain productivity, evaluated in the environments $\mathrm{j}$ and $\mathrm{j}^{\prime}, \hat{V}\left(Y_{j}\right)$ is the phenotypic variance of grain productivity in environment $\mathrm{j}$, and $\hat{V}\left(Y_{j^{\prime}}\right)$ is the phenotypic variance of grain productivity in environment j'.

The genotypic correlation coefficient was estimated by:

$$
r_{g}=\frac{\hat{\phi}_{g\left(i j^{\prime}\right)}}{\phi_{g\left(i j^{\prime}\right)}+\phi_{g a\left(j^{\prime}\right)}}
$$

where $\hat{\phi}_{g(\mathrm{ij})}$ is the genetic variability of grain productivity between environments j and j' and $\hat{\phi}_{\mathrm{g}(\mathrm{jj})}$ is the interaction variability. method:

The genotype determination coefficient $\left(\mathrm{h}^{2}\right)$ was estimated based on the variance analysis

$$
\begin{gathered}
\mathrm{h}^{2}=\frac{\hat{\phi}_{\mathrm{g}}}{Q M T /_{r}} \\
\mathrm{~h}^{2}=\hat{\phi}_{\mathrm{g}}=\frac{\mathrm{QMT}-\mathrm{QMR}}{\mathrm{r}}
\end{gathered}
$$

where $h^{2}$ is the genotypic determination coefficient, $\hat{\phi}_{\mathrm{g}}$ is the genetic quadratic component, QMT is the genotype mean square, QMR is the residual mean square, and $r$ is the number of repetitions.

The statistical significance of the phenotypic correlation coefficient was tested with the Student $t$-test at $5 \%$ probability. In addition, the phenotypic stability and adaptability were analyzed using the methods of Eberhart and Russel (1966), Lin and Binns (1998), modified by Carneiro (1998), and AMMI analysis. Statistical analyses were performed with the programs Gene (computer application in genetics and statistics; Cruz, 2006) and Stability (Ferreira, 2002).

\section{RESULTS AND DISCUSSION}

The joint variance analysis showed that there was a significant $G \times E$ interaction (F-test, 
$P<0.01$ ), which indicates differences in productivity of soy genotypes between the different environments (Table 3). Therefore, it is difficult to recommend the use of a specific cultivar in a municipality, since depending on the location the productivity is different. Hence, it is important to study the adaptability and stability of the lineages.

Average grain productivity was $2739.26 \mathrm{~kg} / \mathrm{ha}$, which was below the average for Goiás (2965 kg/ha) and above the average for Bahia $(2100 \mathrm{~kg} / \mathrm{ha})$ for the $2012 / 13$ season. It should be noted that rainfall occurred at the time of harvesting, which may have contributed to the low grain productivity (CONAB, 2013). Nevertheless, among the studied genotypes, specific lineages adapted to the different regions can be selected.

The coefficient of variation $(\mathrm{CV}, \%)$ indicated an appropriate accuracy of the results $(\mathrm{CV}=$ $15.99 \%$; Table 3), showing that causes of systematic variations in the different environments were under control. This result falls within the maximum acceptable limit for the variation coefficient of soybean productivity tests of $16 \%$, as suggested by Carvalho et al. (2003).

Table 3. Summary of the joint variance analysis of grain productivity $(\mathrm{kg} / \mathrm{ha})$ in five lineages and two cultivars, in the agricultural years of 2010/11, 2011/12, and 2012/13, in seven environments.

\begin{tabular}{l|c|c}
\hline Source of variation & Degrees of freedom & Mean squares \\
\hline Blocks/Environment & 14 & $520,007.43$ \\
\hline Genotypes (G) & 6 & $2,281,360.17^{\text {ns }}$ \\
\hline Environment (E) & 6 & $12,763,101.60^{\text {ns }}$ \\
\hline G $\mathrm{E}$ & 36 & $1,190,862.76^{\star *}$ \\
\hline Error & 84 & $192,021.78$ \\
\hline Mean & & $2,739.26$ \\
\hline $\mathrm{CV}(\%)$ & & 15.99 \\
\hline $\mathrm{h}^{2}(\%)$ & & 47.80 \\
\hline
\end{tabular}

${ }^{* *}$ Significant at the $1 \%$ probability level using the F-test and the coefficient of variation (CV, \%); $h^{2}$ : genotypic determination coefficient.

Moreover, the National Registry of Cultivars (RNC) considers that only trials with a CV lower than $20 \%$ are acceptable for determination of the VCU in soybean cultivars (Brasil, 1998). Therefore, the results obtained in the present study may be considered accurate. During the enhancement process, genotypes are fixed and pre-determined. The heritability parameter $\left(\mathrm{h}^{2}\right)$, also called genotypic determination coefficient, gives the proportion of the genetic variability present in the total phenotypic variance (Ramalho et al., 2012). In this study, $\mathrm{h}^{2}$ was $47.80 \%$ (Table 3 ), which is lower than the value estimated by Yokomizo and Vello (2000) (57.57\%). This difference may be due to the strong influence of environmental conditions on agricultural characters, which is common in quantitative characters such as productivity.

In the season 2011/12 in Palmeiras de Goiás, the genotypes L01V13, L02V13, L03V13, M-SOY6101, and UFUS Guarani had a higher productivity than the lineages L04V13 and L05V13. The L01V13 lineage showed the highest mean (2908 kg/ha), well above the mean genotype productivity (2739.26 kg/ha) (Table 4). In the season 2012/13, the genotypes from Palmeiras de Goiás that were more productive were L01V13, L04V13, L05V13, and UFUS Guarani. In this municipality, the season 2012/13 was very good for grain production (average productivity of 3924.86 $\mathrm{kg} / \mathrm{ha}$ ), which was higher than the average for the State of Goiás (2965 kg/ha) (CONAB, 2013). In this environment, the cultivar UFUS Guarani reached the highest average grain productivity (5250 $\mathrm{kg} / \mathrm{ha}$ ); productivity was higher than the general average and higher than any other productivity value obtained in this study. When evaluating the productivity of seven soybean cultivars in three different sowing seasons in the municipality of Uberlândia, Marques et al. (2011) also observed that 
UFUS Guarani had a high grain productivity in one the seasons (3125.87 kg/ha). Nevertheless, this value was lower than the one found in this study.

Table 4. Average grain productivity ( $\mathrm{kg} / \mathrm{ha}$ ) of seven soybean genotypes grown in different seasons, in seven environments in the regions of Goiás and Bahia.

\begin{tabular}{l|c|c|c|c|c|c|c|c}
\hline \multirow{2}{*}{ Genotype } & \multicolumn{7}{|c|}{ Environments } & Average \\
& P.G1 & P.G2 & UR.1 & UR.2 & GTB. & L.E.M1 & L.E.M2 & \\
\hline L01V13 & $2908.00^{\mathrm{aBC}}$ & $4722.00^{\mathrm{aA}}$ & $1698.00^{\mathrm{aD}}$ & $2487.33^{\mathrm{aCD}}$ & $3282.67^{\mathrm{aBC}}$ & $3746.33^{\mathrm{abAB}}$ & $3310.00^{\mathrm{abBC}}$ & 3164.90 \\
\hline L02V13 & $2399.00^{\mathrm{abBC}}$ & $2805.00^{\mathrm{bB}}$ & $1546.33^{\mathrm{aC}}$ & $2266.67^{\mathrm{aBC}}$ & $2266.67^{\mathrm{abcBC}}$ & $4244.33^{\mathrm{abA}}$ & $1569.33^{\mathrm{cC}}$ & 2442.48 \\
\hline L03V13 & $2249.00^{\mathrm{abBC}}$ & $3028.00^{\mathrm{bB}}$ & $1878.33^{\mathrm{aC}}$ & $2787.00^{\mathrm{aBC}}$ & $2113.67^{\mathrm{bcBC}}$ & $4199.00^{\mathrm{abA}}$ & $2423.33^{\mathrm{bcBC}}$ & 2668.38 \\
\hline L04V13 & $1696.00^{\mathrm{bB}}$ & $4617.00^{\mathrm{aA}}$ & $1650.67^{\mathrm{aB}}$ & $2016.67^{\mathrm{aB}}$ & $2284.33^{\mathrm{abcB}}$ & $2137.67^{\mathrm{cB}}$ & $2312.33^{\mathrm{bcB}}$ & 2387.80 \\
\hline L05V13 & $1810.67^{\mathrm{bCD}}$ & $4336.00^{\mathrm{aA}}$ & $1560.67^{\mathrm{aD}}$ & $2649.33^{\mathrm{aBC}}$ & $1731.67^{\mathrm{cCD}}$ & $3445.00^{\mathrm{abAB}}$ & $3211.00^{\mathrm{abB}}$ & 2677.76 \\
\hline M-SOY6101 & $2705.34^{\mathrm{abAB}}$ & $2716.00^{\mathrm{bAB}}$ & $1789.67^{\mathrm{aB}}$ & $2943.33^{\mathrm{aA}}$ & $3149.33^{\mathrm{adA}}$ & $3186.00^{\mathrm{bCA}}$ & $1785.67^{\mathrm{cB}}$ & 2610.76 \\
\hline Guarani & $2542.00^{\mathrm{abC}}$ & $5250.00^{\mathrm{aA}}$ & $1407.33^{\mathrm{aD}}$ & $2249.67^{\mathrm{aCD}}$ & $2775.33^{\mathrm{adcC}}$ & $4319.67^{\mathrm{aAB}}$ & $4015.00^{\mathrm{aB}}$ & 3222.71 \\
\hline Average & 2330.0 & 3924.86 & 1647.29 & 2485.71 & 2514.81 & 3611.19 & 2660.95 & 2739.26 \\
\hline
\end{tabular}

Averages followed by the same upper case letter in the horizontal axis and averages followed by the same lower case letters in the vertical axis do not differ statistically among each other at the $5 \%$ probability level using the Tukey test. Environments: P.G1 - Palmeiras de Goiás 2011/12; P.G2 - Palmeiras de Goiás 2012/13; UR.1 - Urutaí 2010/11; UR.2 - Urutaí 2011/12; GTB. - Goiatuba 2011/12; L.E.M1 - Luís Eduardo Magalhães 2011/12; L.E.M2 - Luís Eduardo Magalhães 2012/13.

In Urutaí (seasons 2010/11 and 2011/12), all genotypes presented a similar low performance in terms of productivity. The high incidence of rust in this municipality led to losses in grain productivity. In Goiatuba (season 2011/12), the lineage L01V13 had a higher average productivity than the other genotypes, although it did not differ significantly from the genotypes L02V13, L04V13, and the controls M-SOY6101 and UFUS Guarani. In the municipality of Luís Eduardo Magalhães, UFUS Guarani had the highest average in 2011/12, although this value was not significantly different from the values obtained for genotypes L01V13, L02V13, L03V13, and L05V13. Similar results were found in 2012/13, with the genotype UFUS Guarani showing the highest average. Nevertheless, differences between this genotype and the lineages L01V13 and L05V13 were not statistically significant.

The genotypes L01V13 and L05V13, as well as the control UFUS Guarani, had a better performance in terms of productivity in Palmeiras de Goiás (season 2012/13) and Luís Eduardo Magalhães (season 2011/12). In the latter, the genotypes L02V13 and L03V13 had clearly higher productivity than the other genotypes. In Palmeiras de Goiás, which is considered a highly fertile environment, the genotype L04V13 had a significantly higher productivity in 2012/13 than it had in any other environment or sowing season. The cultivar M-SOY6101 did not show any significant difference among environments, except when grown in Urutaí (season 2010/11) and Luís Eduardo Magalhães (season 2012/13).

Average grain productivity varied from $2330 \mathrm{~kg} / \mathrm{ha}$ (Palmeiras de Goiás, 2011/12) to $3924.86 \mathrm{~kg} / \mathrm{ha}$ (Palmeiras de Goiás, 2012/13), with an overall average $2739.26 \mathrm{~kg} / \mathrm{ha}$ (Table 4). The highest productivity was observed in UFUS Guarani (5250 kg/ha) grown in Palmeiras de Goiás in $2012 / 13$. However, this genotype presented also the lowest productivity $(1407.33 \mathrm{~kg} / \mathrm{ha}$; Urutaí, 2010/11).

The analysis of the $G \times E$ interaction between pairs of environments revealed that the pairs Palmeiras de Goiás 2011/12-Goiatuba 2011/12, Palmeiras de Goiás 2012/13-Luís Eduardo Magalhães 2012/13, Urutaí 2010/11-Goiatuba 2011/12, Urutaí 2010/11-Urutaí 2011/12, and Urutaí 2010/11-Luís Eduardo Magalhães 2011/12 showed a simple type of interaction, i.e., the complex 
part of the interaction was lower than 50\% (Table 5), as described by Cruz et al. (2012). Genotype performance in these environments is similar, and, therefore, it is not difficult to give advice on genotype selection.

Table 5. Decomposition of the $\mathrm{G} \times \mathrm{E}$ interaction of soybean lineages grown in seven environments into complex parts (C,\%), following Cruz and Castoldi (1991).

\begin{tabular}{|c|c|c|}
\hline & C (\%) \\
\hline \multicolumn{2}{|l|}{$\begin{array}{l}\text { Environments } \\
\text { Palmeiras de Goiás 2011/12 }\end{array}$} & 79.53 \\
\hline Palmeiras de Goiás 2011/12 & Urutaí 2011/12 & 76.16 \\
\hline Palmeiras de Goiás 2011/12 & Luís Eduardo Magalhães 2011/12 & 52.29 \\
\hline Palmeiras de Goiás 2011/12 & Urutaí 2010/11 & 56.59 \\
\hline Palmeiras de Goiás 2011/12 & Goiatuba 2011/12 & 32.04 \\
\hline Palmeiras de Goiás 2011/12 & Luís Eduardo Magalhães 2012/13 & 75.46 \\
\hline Palmeiras de Goiás 2012/13 & Urutaí 2010/11 & 50.29 \\
\hline Palmeiras de Goiás 2012/13 & Goiatuba 2011/12 & 78.53 \\
\hline Palmeiras de Goiás 2012/13 & Luís Eduardo Magalhães 2012/13 & 33.52 \\
\hline Palmeiras de Goiás 2012/13 & Urutaí $2011 / 12$ & 84.32 \\
\hline Palmeiras de Goiás 2012/13 & Luís Eduardo Magalhães 2011/12 & 103.64 \\
\hline Urutaí 2010/11 & Goiatuba 2011/12 & 45.44 \\
\hline Urutaí 2010/11 & Luís Eduardo Magalhães 2012/13 & 53.95 \\
\hline Urutaí 2010/11 & Urutaí $2011 / 12$ & 34.75 \\
\hline Urutaí $2010 / 11$ & Luís Eduardo Magalhães 2011/12 & 47.35 \\
\hline Urutaí 2011/12 & Luís Eduardo Magalhães 2011/12 & 58.55 \\
\hline Urutaí $2011 / 12$ & Goiatuba 2011/12 & 79.37 \\
\hline Urutaí 2011/12 & Luís Eduardo Magalhães 2012/13 & 74.52 \\
\hline Goiatuba 2011/12 & Luís Eduardo Magalhães 2011/12 & 93.41 \\
\hline Goiatuba 2011/12 & Luís Eduardo Magalhães 2012/13 & 85.37 \\
\hline Luís Eduardo Magalhães 2011/12 & Luís Eduardo Magalhães 2012/13 & 86.03 \\
\hline
\end{tabular}

All other pairs of environments showed a complex type of interaction, indicating differences in the behavior of genotypes in response to environmental variation. In these cases, it is difficult to provide advice on the performance of cultivars and lineages (Cruz et al., 2012) and it is impossible to recommend the use of one cultivar suitable for all environments. Barros et al. (2008) evaluated 30 genotypes of soybean in six environments and found simple interactions in two pairs of environments and complex interactions in the remaining pairs. Barros et al. (2009) found similar results in a study with 29 genotypes in six environments, with all pairs of environments presenting complex interactions. In a study with 11 cultivars, in eight environments in the State of Tocantins (Brazil), Carvalho et al. (2013) showed complex interactions in terms of productivity among all the pairs of environments.

The analysis of the decomposition of the $G \times E$ interaction was for one pair of environments (Palmeiras de Goiás 2012/13-Luís Eduardo Magalhães 2011/12) higher than 100\% (Table 5). This happens when the correlation between environments is negative (Cruz et al., 2012). Pelúzio et al. (2008) found a similar result when evaluating 20 soybean cultivars during four sowing seasons in the municipality of Gurupi.

According to Eberhart and Russel (1966), the ideal genotype is the one with high average productivity $\left(\beta_{0}\right), \beta_{1 \mathrm{i}}$ equal to 1 and non-significant deviations from the regression. The L01V13 and L05V13 lineages presented high grain productivity, with a $\beta_{1 i}$ close to 1 (Table 6). Therefore, they are considered to have wide adaptation. Since the deviations from the regression were not significant and the coefficients of determination were higher than $80 \%$ (Table 6), these lineages are expected to have high productivity. 
Table 6. Average grain productivity $(\mathrm{kg} / \mathrm{ha})$ and estimates of adaptability and stability in seven soybean genotypes grown in seven environments, following the methods described by Eberhart and Russel (1966) and Lin and Binns (1988), with modifications by Carneiro (1998).

\begin{tabular}{l|c|c|c|c|c|c|c}
\hline \multirow{2}{*}{ Genotypes } & \multicolumn{3}{|c|}{ Eberhart and Russel $(1966)$} & \multicolumn{3}{c}{ Lin and Binns (1988), modified by Carneiro (1998) } \\
\cline { 2 - 8 } & $\beta_{0}$ & $\beta_{1 i}$ & $\sigma_{\text {di }}$ & $R^{2}$ & Pigeneral & Pifavorable & Piunfavorable \\
\hline L01V13 & 3164.90 & $1.15^{\text {ns }}$ & $66158.29^{\text {ns }}$ & 88.11 & 96069.72 & 151873.75 & 73748.11 \\
\hline L02V13 & 2442.48 & $0.86^{\text {ns }}$ & $393355.87^{* \star}$ & 54.33 & 987458.85 & 1495925.02 & 784072.38 \\
\hline L03V13 & 2668.38 & $0.80^{\text {ns }}$ & $202810.21^{\text {ns }}$ & 63.49 & 665032.08 & 1237941.00 & 435868.51 \\
\hline L05V13 & 2387.81 & $0.99^{\text {ns }}$ & $452456.29^{* *}$ & 58.40 & 816931.64 & 1290452.98 & 627523.10 \\
\hline M-SOY6101 & 2677.76 & $1.20^{\text {ns }}$ & $183893.47^{\text {ns }}$ & 80.98 & 431710.25 & 400109.37 & 444350.61 \\
\hline UFUS Guarani & 2610.76 & $0.37^{\star *}$ & $258286.09^{*}$ & 23.50 & 910214.03 & 1926588.94 & 503664.07 \\
\hline
\end{tabular}

** Significant at the $1 \%$ probability level using the Student $t$-test and the F-test; *significant at the $5 \%$ probability level using the Student $t$-test and the F-test; ns: non-significant.

The cultivar M-SOY6101 showed a $\beta_{1 \mathrm{i}}$ smaller than 1, suggesting adaptation to unfavorable environments. However, the coefficient of determination was low $(<70 \%)$ and deviations were significant, indicating low behavior predictability. This result corroborates the findings of Polizel et al. (2013), who also observed an $R^{2}$ smaller than $70 \%$ for this cultivar. These authors used the method proposed by Eberhart and Russel (1966) to evaluate the adaptability and stability of 16 soybean lineages (developed by the soybean enhancement program of the Universidade Federal de Uberlândia - UFU) with four controls, among which the cultivar M-SOY6101. The cultivar UFUS Guarani presented a good response capacity to improvements in the environment, adapting well to favorable environments. This cultivar showed a regression coefficient higher than 1 and a high average grain productivity. However, it had low predictability as shown by the significant regression deviation.

Using the Lin and Binns (1988) method, modified by Carneiro (1998), the cultivar UFUS Guarani and the lineages L01V13 and L05V13 had the highest average grain productivity and stability considering general environmental conditions, as demonstrated by the low general $\mathrm{Pi}$ value (Table 6). These results agree with those obtained using the Eberhart and Russel (1966) method; in the latter, the lineages L01V13 and L05V13 were considered to have wide adaptation. In a study with seven soybean cultivars, Marques et al. (2011) also obtained similar results with both methods for the cultivar UFUS Xavante.

The cultivar UFUS Guarani and the lineages L01V13 and L05V13 had a better performance in the favorable environment (low Pi value), indicating that these genotypes are more responsive to this type of environment. Regarding unfavorable environments, the lineages that had the best performance were L01V13, L03V13, and control UFUS Guarani, showing that they are better adapted to this type of environment. Both classification methods considered that UFUS Guarani was well adapted to the favorable environment.

An AMMI analysis was done to study the adaptability and stability of soybean genotypes using the $\mathrm{AMMI}_{2}$ model. In this analysis, the first two principal components should account for $70 \%$ or more of the cumulative total variance explained, capturing the greatest amount of the variation and causing a decrease in variation of the subsequent components (Ramalho et al., 2012). Therefore, with the increase in the number of principal components, the percentage of noise increases and the predictive power of the analysis decreases (Oliveira et al., 2003).

In terms of decomposition of the $\mathrm{G} \times \mathrm{E}$ interaction using the AMMI model, it was observed that all principal components were significant (Table 7). Sousa (2013) has found similar results in a study on the stability and adaptability of cultivars in five municipalities of Mato Grosso, using genotypes developed by the soybean enhancement program of the UFU. However, in a study 
on the selection of soybean genotypes with high grain productivity and resistance to Asian rust, Yokomizo et al. (2013) found that only the first two principal components were significant.

Table 7. Proportion of sum of squares in G $\mathrm{E}$ interaction for each principal component of the AMMI analysis for
seven environments and genotypes.
\begin{tabular}{l|c|c}
\hline Principal component & Explained variance (\%) & Cumulative explained variance (\%) \\
\hline CP1 $^{* *}$ & 58.24 & 58.24 \\
\hline CP2 $^{* *}$ & 17.84 & 76.08 \\
\hline CP3 $^{* *}$ & 16.28 & 92.37 \\
\hline CP4 $^{* *}$ & 5.31 & 97.67 \\
\hline CP5 & 2.20 & 99.88 \\
\hline CP6 & 0.12 & 100.0 \\
\hline
\end{tabular}

**Significant at the $1 \%$ probability level; *significant at the $5 \%$ probability level.

Using the $\mathrm{AMMI}_{2}$ model, the first two principal components (CP1 and CP2) accounted for $76.08 \%$ of the cumulative total variance explained (Table 7). Therefore, the biplot resulting from this model was used to interpret the results. A similar procedure has been used in several studies on the adaptability and phenotypic stability of soybean genotypes (Asfaw et al., 2009; Martins and Juliatti, 2012; Sousa, 2013; Yokomizo et al., 2013). For the interpretation of stability, the distance between the points representing the genotypes and environments to the zero score was considered. The points contributing less to the interaction are represented by a smaller distance, indicating greater stability. The adaptability of the genotypes to each environment was analyzed using the scores obtained for genotypes and environments, because genotypes and environments with the same score signal interact positively. Such genotypes can be widely recommended since they have high averages (Duarte and Vencovsky, 1999). The genotypes and environments with scores close to zero (center of the biplot) are considered more stable (Duarte and Vencovsky, 1999).

The genotype L05V13 was the most stable, followed by the L04V13 genotype (Figure 1). The values -15 and +15 of the CP2 axis were used as the limits. According to Polizel et al. (2013), the detection of stable genotypes is an extremely important factor in enhancement practices. The AMMI analysis is a statistic tool that helps the interpretation of test results in enhancement programs.

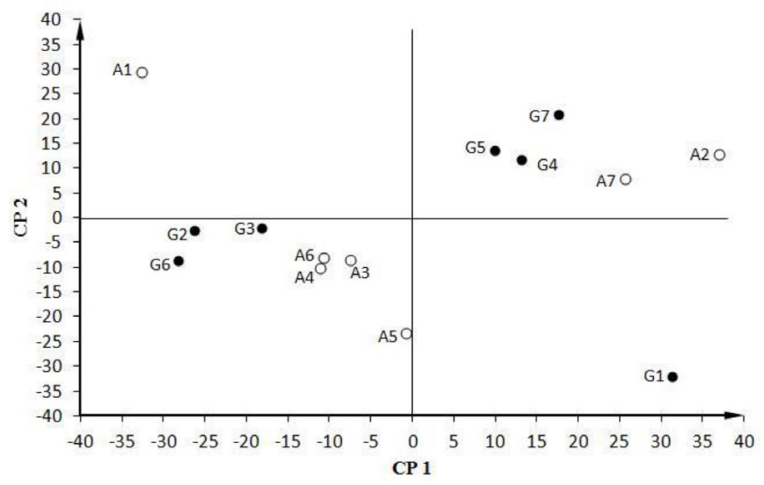

Figure 1. PCA of the first two principal components in relation to their environmental stratification, according to the $\mathrm{AMMI}_{2}$ model for grain productivity. Seven genotypes of soybeans were analyzed in different annual cycles [G1 (L01V13), G2 (L02V13), G3 (L03V13), G4 (L04V13), G5 (L05V13), G6 (M-SOY6101), and G7 (UFUS Guarani)] and seven environments [A1 (Palmeiras de Goiás - 2011/2012), A2 (Palmeiras de Goiás - 2012/2013), A3 (Urutaí 2010/2011), A4 (Urutaí - 2011/2012), A5 (Goiatuba - 2011/2012), A6 (Luís Eduardo Magalhães - 2011/2012), and A7 (Luís Eduardo Magalhães - 2012/2013)]. CP1: principal component 1; CP2: principal component 2. 
The L01V13 and L02V13 genotypes and the M-SOY6101 and UFUS Guarani cultivars showed a low stability. These genotypes contributed most to the $G \times E$ interaction. In general, more stable genotypes contributed less to the $G \times E$ interaction and presented lower productivity than the other genotypes. More unstable genotypes, which contributed more to the $G \times E$ interaction, presented higher productivity. We aimed, therefore, to find stable genotypes that had high yield. The most stable genotype, L05V13, showed an average grain productivity of $2677.76 \mathrm{~kg} / \mathrm{ha}$ (Table 4), which was $2.2 \%$ lower than the overall genotype average (considering all environments). However, its productivity is considered satisfactory since it is higher than the average for Bahia (2100 kg/ha) (CONAB, 2013).

The genotypes L01V13 and UFUS Guarani, classified as unstable, had an average productivity of 3164.9 and $3222.71 \mathrm{~kg} / \mathrm{ha}$, respectively, which were higher than the average for Goiás (Table 4). Amira et al. (2013) found similar results using the AMMI analysis: the six more unstable soybean genotypes presented higher grain productivity.

The environment that contributed less to the $G \times E$ interaction (therefore, the most stable) was Urutaí, in the season 2010/11. In contrast, Palmeiras de Goiás (2011/12), Palmeiras de Goiás (2012/13), and Goiatuba (2011/12) contributed most to the interaction. These environments were quite different from each other regarding the $\mathrm{G} \times \mathrm{E}$ interaction.

The $\mathrm{AMMI}_{2}$ model enabled the identification of genotypes with specific adaptations, by taking into account the score proximity between genotypes and environments. The genotypes L05V13 and L04V13, and the cultivar UFUS Guarani (characterized by high productive potential), were more adapted and stable in Luís Eduardo Magalhães (2012/2013). In this municipality, where 1.1 million hectares are planted with soybeans, advanced technology is used, resulting in a production of 2.8 million tons of soybeans (CONAB, 2013). Hence, this municipality is considered a highly favorable environment for the production of soybeans.

The genotypes L03V13 and L02V13, and the cultivar M-SOY6101, which had a higher average grain productivity than the average in Bahia, adapted well to the environmental conditions of Luís Eduardo Magalhães (2011/12) and Urutaí (2011/12) (Figure 1). In these municipalities, temperature is favorable for soybean cultivation.

Both the AMMI analysis and the Eberhart and Russel (1966) method classified the genotype L05V13 as being highly stable.

\section{Conflicts of interest}

The authors declare no conflict of interest.

\section{ACKNOWLEDGMENTS}

We thank the Coordination for Personal Perfection in Higher Education (Coordenação de Aperfeiçoamento de Pessoal de Nível Superior - CAPES) and Fundação de Amparo à Pesquisa do Estado de Minas Gerais (FAPEMIG) for the financial support.

\section{REFERENCES}

Amira JO, Ojo DK, Ariyo OJ, Oduwaye OA, et al. (2013). Relative discriminating powers of GGE and AMMI models in the selection of tropical soybean genotypes. Afr. Crop Sci. J. 21: 67-73.

Asfaw A, Alemayehu F, Gurum F and Atnaf M (2009). AMMI and SREG GGE biplot analysis for matching varieties onto soybean production environments in Ethiopia. Sci. Res. Essays 4: 1322-1330. 
Barros HB, Sediyama T, Teixeira RC and Cruz CD (2008). Análises paramétricas e não-paramétricas para determinação da adaptabilidade e estabilidade de genótipos de soja. Sci. Agric. 9: 299-309.

Barros HB, Sediyama T, Teixeira RC, Reis MS, et al. (2009). Adaptabilidade e Estabilidade de Genótipos de Soja, no Estado do Mato Grosso. Biosci. J. 25: 119-128.

Brasil - Ministério da Agricultura e do Abastecimento (1998). Anexo VI. Requisitos mínimos para determinação do valor de cultivo e uso de soja (Glycine max L.), para a inscrição no registro nacional de cultivares - RNC. http://www.agricultura. gov.br/vegetal/registros-autorizacoes/registro/registro-nacional-cultivares/formularios-registro-cultivares-requisitos. Accessed December 20, 2014.

Carneiro PCS (1998). Novas metodologias de análise da adaptabilidade e estabilidade de comportamento. Doctoral thesis, Departamento de Fitotecnia, Universidade Federal de Viçosa, Viçosa.

Carvalho EV, Peluzio JM, Santos WF, Afférri FS, et al. (2013). Adaptabilidade e estabilidade de genótipos de soja em Tocantins. Ver. Agroambiente On-line 7: 162-169.

Chawla S, Bowen CR, Slaminko TL, Hobbs HA, et al. (2013). A public program to evaluate commercial soybean cultivars for pathogen and pest resistance. Plant Dis. 97: 568-578. http://dx.doi.org/10.1094/PDIS-05-12-0479-FE

CONAB - Companhia Nacional de Abastecimento (2013). Acompanhamento da safra brasileira: grãos - nono levantamento. Brasilia. http://www.conab.gov.br/OlalaCMS/uploads/arquivos/13_06_06_09_09_27_boletim_graos_-junho_2013.pdf. Accessed November 13, 2014.

CONAB - Companhia Nacional de Abastecimento (2014). Acompanhamento da safra brasileira: grãos - décimo segundo levantamento. Brasília. http://www.conab.gov.br/OlalaCMS/uploads/arquivos/14_09_10_14_35_09_boletim_graos_ setembro_2014.pdf. Accessed January 22, 2015.

Cruz CD (2006). Programa GENES: aplicativo computacional em genética e estatística. Universidade Federal de Viçosa, Viçosa.

Cruz CD and Castoldi FL (1991). Decomposição da interação genótipo x ambiente em parte simples e complexa. Ver. Ceres 38: 422-430.

Cruz CD, Regazzi AJ and Carneiro PCS (2012). Modelos biométricos aplicados ao melhoramento genético. Universidade Federal de Viçosa, Viçosa.

Duarte JB and Vencovsky R (1999). Interação genótipos x ambientes - uma introdução á análise "AMMI". Sociedade Brasileira de Genética, Ribeirão Preto.

Eberhart SA and Russel WA (1966). Stability parameters for comparing varieties. Crop Sci. 6: 36-40. http://dx.doi.org/10.2135/ cropsci1966.0011183X000600010011x

EMBRAPA - Empresa Brasileira de Pesquisa Agropecuária (2010). Desenvolvimento, mercado e rentabilidade da soja. Circular Técnico 74, Londrina.

EMBRAPA - Empresa Brasileira de Pesquisa Agropecuária (2011). Tecnologias de produção de soja, região central do Brasil 2012 e 2013. EMBRAPA Soja, Londrina.

Fehr WR and Caviness CE (1977). Stages of soybean development. Special Report 80, State University, lowa.

Ferreira DF (2002). Programa Estabilidade. Available at [www.dex.ufla.br]. Accessed November 20, 2014.

Lemos LB, Farinelli R, Cavariani C and Zapparoli RA (2011). Desempenho agronômico e produtivo de cultivares de soja em diferentes safra. Científica 39: 44-51.

Lin CS and Binns MR (1988). A method of analyzing cultivar $x$ location $x$ year experiments: a new stability parameter. Theor. Appl. Genet. 76: 425-430. http://dx.doi.org/10.1007/BF00265344

Malosetti M, Ribaut JM and van Eeuwijk FA (2013). The statistical analysis of multi-environment data: modeling genotype-byenvironment interaction and its genetic basis. Front. Physiol. 4: 44. http://dx.doi.org/10.3389/fphys.2013.00044

Marques MC, Hamawaki OT, Sediyama T, Bueno MR, et al. (2011). Adaptabilidade e estabilidade de genótipos de soja em diferentes épocas de semeadura. Biosci. J. 27: 59-69.

Martins JAS and Juliatti FC (2012). Adaptability and stability of soybean advanced lines of semi early cycle for rust resistance. Crop Breed. Appl. Biotechnol. 12: 43-51. http://dx.doi.org/10.1590/S1984-70332012000100006

Oliveira AB, Duarte JB and Pinheiro JB (2003). Emprego da Análise AMMI na avaliação da estabilidade produtiva em soja. Pesquisa Agropecu. Bras. 38: 357-364. http://dx.doi.org/10.1590/S0100-204X2003000300004

Oliveira LG, Hamawaki OT, Simon GA, Sousa LB, et al. (2012). Adaptabilidade e estabilidade da produtividade de soja em duas regiões sojícolas. Biosci. J. 28: 852-861.

Pelúzio JM, Fidelis RR, Giongo P, Silva JC, et al. (2008). Adaptabilidade e estabilidade de cultivares de soja em quatro épocas de semeadura no sul do Estado do Tocantins. Ceres 55: 34-40.

Polizel AC, Juliatti FC, Hamawaki OT, Hamawaki RL, et al. (2013). Adaptabilidade e estabilidade fenotípica de genótipos de soja no estado do Mato Grosso. Biosci. J. 29: 910-920.

Ramalho MAP, Abreu AFB, Santos JB and Nunes JAR (2012). Aplicações da genética quantitativa no melhoramento de plantas autógamas. Universidade Federal de Lavras, Lavras. 
Ribeiro AC, Guimarães PTG and Alvarez VH (1999). Recomendações para o uso de corretivos e fertilizantes em Minas Gerais. SBCS, Belo Horizonte.

Rural Economy Department (2013). Soja - Análise da Conjuntura Agropecuária. http://www.agricultura.pr.gov.br/arquivos/File/ deral/Prognosticos/soja_2013_14.pdf. Accessed January 22, 2015.

Sediyama T, Teixeira RC and Reis MS (2005). Melhoramento de Soja. In: Melhoramento de espécies cultivadas (Borém A, eds.). Universidade Federal de Viçosa, Viçosa, 553-604.

Silva WJ and Duarte JB (2006). Métodos estatísticos para estudo de adaptabilidade e estabilidade fenotípica em soja. Pesquisa Agropecu. Bras. 41: 23-30. http://dx.doi.org/10.1590/S0100-204X2006000100004

Sousa LB (2013). Melhoramento genético de soja: diversidade fenotípica e molecular, correlações entre caracteres e adaptabilidade e estabilidade por métodos multivariados. Doctoral thesis. Instituto de Ciências Agrárias, Universidade Federal de Uberlândia, Uberlândia.

Yokomizo GK and Vello NA (2000). Coeficiente de determinação genotípica e de diversidade genética em topocruzamentos de soja tipo alimento com tipo grão. Pesquisa Agropecu. Bras. 35: 2223-2228. http://dx.doi.org/10.1590/S0100$\underline{204 X 2000001100014}$

Yokomizo GK, Duarte JB, Vello NA and Unfried JR (2013). Análise AMMI da produtividade de grãos em linhagens de soja selecionadas para resistência à ferrugem asiática. Pesquisa Agropecu. Bras. 48: 1376-1384. http://dx.doi.org/10.1590/ $\underline{\text { S0100-204X2013001000009 }}$ 